\title{
DO ECONOMIC FORECASTERS BELIEVE THE STOCK MARKET IS EFFICIENT? EVIDENCE FROM GERMANY
}

\author{
Richard Deaves'; Michael Schröder2; Adam Stivers3*; Ming Tsang3 \\ 1. McMaster University, Canada \\ 2. ZEW - Leibniz Centre for European Economic Research, Germany \\ 3. University of Wisconsin-La Crosse, Unites States of America
}

* Corresponding Author: Adam Stivers, College of Business Administration, Department of Finance, University of Wisconsin-La Crosse, 1725 State St., La Crosse, WI, 54601, $₫$ astivers@uwlax.edu

\begin{abstract}
The perception of market efficiency is quite different from the reality of market efficiency. We show using a large survey of German market forecasters that few respondents consistently believe that the stock market is currently efficient and will remain so. Past volatility tends to erode the view that the market is efficient and strengthen the belief that the market is inefficient.
\end{abstract}

JEL codes: G14; D83; D84

Keywords: market efficiency; investor beliefs; forecasting.

\section{Introduction}

A long-running debate in financial economics is the extent to which financial markets embody informational efficiency. While we do not expect prices to be precisely equivalent to intrinsic values at all times according to a strict "price-is-right" version of efficiency because there have to be incentives for analysis (Grossman and Stiglitz, 1980), proponents of efficiency argue that prices are close enough to correct levels most of the time so that abnormal returns are not available to investors net of analysis and transaction costs (Fama, 1998). The evidence is famously inconclusive. ${ }^{1}$ One problem is the data can be read in different ways: one researcher's anomaly is another researcher's risk premium (McLean and Pontiff, 2016). Relative pricing controversies can be avoided by aggregation to the level of the market, with the question then reframed to whether or not market index levels are "right." Again, problematically, abundant work pointing at aggregate return predictability can be read as inefficiency and/or time-varying risk premia (e.g., Campbell and Thompson, 2008; Welch and Goyal, 2008; Kelly and Pruitt, 2013).

The once-firmly-held academic view in favor of the efficient market hypothesis can perhaps best be summarized by the words of Michael Jensen (1978): "I believe there is no other proposition in economics which has more solid empirical evidence supporting it than the Efficient Market Hypothesis." Despite Jensen's perhaps-optimistic statement (which predated the establishment of the iconoclastic finance sub-field of behavioral finance), the jury remains out on the extent to which markets are efficient. ${ }^{2}$ Recently, an alternative to the efficient

I See Shleifer (2000) and Ackert and Deaves (2009) for numerous references.

2 For a survey on empirical findings related to market efficiency, see Lim and Brooks (2011). 
market hypothesis has gained favor in the form of the adaptive market hypothesis. According to one alternative to perfect efficiency, the adaptive market hypothesis of Lo (2019), efficiency (i.e., return predictability) is time-varying and path-dependent due to wellestablished investor heuristics. Evidence of time-varying predictability that is consistent with the adaptive market hypothesis has been reported by Kim, Shamsuddin, and Lim (2011) and Urquhart and McGroarty (2016). In other recent research, Bartram and Grinblatt (2018) find evidence against market efficiency, in that a naïve fundamental analysis can earn significant risk-adjusted returns; Manconi et al. (2019) find that on average share repurchases are associated with significant positive short- and long-term excess returns; and Fang et al. (2014) report that fund families are aware of the inefficiencies in some market segments and attempt to exploit inefficiencies through fund manager allocations. Other research, however, points to practices that appear to facilitate market efficiency: Purnanandam and Serhun (2018) find that short sellers on average make markets more efficient, while Chen, Kelly, and Wu (2020) report that after reduced analyst coverage, hedge funds' information acquisition and trading behavior mitigate the impairment of information efficiency caused by coverage reduction.

The reality of efficiency, whatever that may be, may or may not be the same as the perception of efficiency. Moreover, what academic researchers believe on the notion of efficiency may diverge widely from what private sector forecasters and practitioners believe. Indeed, it can be argued that the reality of efficiency requires the perception of some degree of inefficiency (Williams and Paton, 1997). The purpose of this paper is to provide some evidence on the level of market efficiency as perceived "in the real world." Thus, we investigate how often time-invariant efficiency views (versus perceived inefficiencies) are held in the real world.

Specifically, we examine beliefs on efficiency as revealed by the ZEW Finanzmarkttest, a monthly survey of over 200 private sector forecasters in Germany. ${ }^{3}$ From 1991 to the present, this survey has solicited directional predictions (rise/fall/unchanged) for a series of key macroeconomic and financial market variables for the key industrialized economies as of six months in the future, one of which is the DAX, a broad German stock market index. Starting in 2003, ZEW survey respondents were also asked to provide quantitative forecasts, namely point estimates and $90 \%$ confidence intervals for the DAX six months ahead. Still later, starting in 2011 , participants were asked whether they believed the DAX to be correctly priced. Since these last two questions are at the heart of this study, we repeat them (in their English translations):

1. Six months ahead, l expect the DAX to stand at $90 \%$ the DAX will then range between survey. Respondents are expected to fill in three blanks.) points. With a probability of and points. (Question $6 \mathrm{~b}$ in

2. In view of the fundamentals of the DAX companies the DAX is currently overpriced [ ] fairly priced [ ] under-priced [ ]. (Question 6c in survey. Respondents are expected to tick one box.)

The set of answers to these questions over time is the dataset used in this study. It allows us to observe the extent to which market practitioners believe the market to be efficient. ${ }^{4}$ Importantly, it is possible to observe the form of any perceived inefficiency. For each

\footnotetext{
3 This survey has been used in other research papers investigating market efficiency. For example, Deaves, Lüders, and Schröder (2010) use it to draw inferences on the extent to which market forecasters exhibit overconfidence.

4 In quasi-related work, Shah, Ahmad, and Mahmood (2018) utilize a set of categorical questions to proxy for views on efficiency and examine how those views impact the prevalence of biases such as overconfidence.
} 
forecaster at each point in time, we can slot survey responses according to the $3 \times 3$ matrix below.

\begin{tabular}{|c|c|c|c|c|}
\hline & & & \\
\hline & & \multicolumn{3}{|c|}{ FORECAST (Question 6b) } \\
\hline & & $\begin{array}{c}\text { Below trend } \\
\text { (BT) }\end{array}$ & $\begin{array}{l}\text { Equal to trend } \\
\text { (ET) }\end{array}$ & Above Trend (AT) \\
\hline \multirow{3}{*}{$\begin{array}{l}\text { VALUATION } \\
\text { (Question } \\
\text { 6c) }\end{array}$} & $\begin{array}{c}\text { Overvaluation } \\
\text { (OV) }\end{array}$ & 1. Temporary OV & 2. Steady OV & 3. Bubble \\
\hline & $\begin{array}{c}\text { Fair valuation } \\
\text { (FV) }\end{array}$ & 4. Becoming UV & 5. EFFICIENCY & 6. Becoming OV \\
\hline & $\begin{array}{c}\text { Undervaluation } \\
\text { (UV) }\end{array}$ & 7. Reverse Bubble & 8. Steady UV & 9. Temporary UV \\
\hline
\end{tabular}

The rows correspond to question $6 c$ and respondent views on over-, under-, or fair valuation. The columns correspond to question $6 \mathrm{~b}$, with the middle column containing forecasts "equal to trend." For present purposes, this means a forecast is within an interval centered on the past average return of the DAX. The first and last columns are for below-/above-trend cases. Some judgment of course is required for what constitutes a forecast close to trend, so we consider several intervals.

The nine cells in this matrix constitute various views on the nature of current and future inefficiency (if any). Cell \#5 is synonymous with time-invariant efficiency: the DAX is correctly valued today, and the forecast is equal to trend so it will be correctly valued in the future. There are four pairs of cells that suggest variants of current and/or future perceived inefficiency:

1. Cells \# 1 and \#9. Temporary mis-valuation. The forecaster believes that the market is currently overvalued (\#1)/undervalued (\#9), but it will move towards its correct level over the next six months. This is because when the market is overvalued, the forecast is for below trend, and when undervalued the forecast is for above trend.

2. Cells \#4 and \#6. Correct valuation with sentiment about to appear. In one case (\#6), positive sentiment will push the DAX into overvaluation, while in another case (\#4) negative sentiment will push the DAX into undervaluation.

3. Cells \#3 and \#7. Bubbles or reverse bubbles. In one case (\#3), there is the view that the market is overvalued and, because the forecast is above trend, will become even more overvalued (reminiscent of a bubble). In the second case (\#7), we have undervaluation and a below-trend forecast, or what may be termed a "negative bubble."

4. Cells \#2 and \#8. Steady overvaluation or undervaluation. In Cell \#2/Cell \#8 the forecaster believes that the DAX is overvalued/undervalued but the extent of mis-valuation should not change much with the forecast being at trend.

With these data, we address the following questions. First, what percentage of forecasters believe that the market is correctly valued? Second, given perceived inefficiency, what are on average the more common forms of inefficiency? Third, we consider time-variation and institution-variation in efficiency beliefs. Fourth, given this variation, are there variables that are useful in predicting whether forecasters will continue in their efficiency vs. inefficiency beliefs? The next section provides some empirical evidence, with a final section concluding. 


\section{Results}

First, how common is a belief in efficiency? We use intervals of $0.25,0.50$ and 0.75 standard deviations above and below the historical mean of the six-month DAX return to signify the "trend," but concentrate discussion on the middle value. Table 1 shows average percentages within each of the nine cells across time and institutions. We also aggregate the cell-pairs $1 \& 9,4 \& 6,3 \& 7$, and $2 \& 8$ as suggested by the discussion in the previous section, as well as the cell triplets corresponding to fair valuation (4\&5\&6), overvaluation (1\&2\&3) and undervaluation (7\&8\&9).

Table 1: Percentage of Responses in Each Cell

\begin{tabular}{|c|c|c|c|}
\hline Cells & 0.75 SD & 0.5 SD & 0.25 SD \\
\hline 1 & $3.98 \%$ & $7.06 \%$ & $10.18 \%$ \\
\hline 2 & $11.58 \%$ & $8.24 \%$ & $4.44 \%$ \\
\hline 3 & $0.20 \%$ & $0.46 \%$ & $1.14 \%$ \\
\hline 4 & $4.19 \%$ & $8.57 \%$ & $20.52 \%$ \\
\hline 5 & $57.11 \%$ & $51.01 \%$ & $33.43 \%$ \\
\hline 6 & $1.41 \%$ & $3.13 \%$ & $8.76 \%$ \\
\hline 7 & $0.26 \%$ & $0.68 \%$ & $1.92 \%$ \\
\hline 8 & $18.78 \%$ & $16.30 \%$ & $10.45 \%$ \\
\hline 9 & $2.47 \%$ & $4.54 \%$ & $9.15 \%$ \\
\hline 189 & $6.45 \%$ & $11.60 \%$ & $19.33 \%$ \\
\hline 486 & $5.60 \%$ & $11.70 \%$ & $29.28 \%$ \\
\hline $3 \& 7$ & $0.46 \%$ & $1.14 \%$ & $3.06 \%$ \\
\hline 288 & $30.36 \%$ & $24.54 \%$ & $14.89 \%$ \\
\hline 5 & $57.11 \%$ & $51.01 \%$ & $33.43 \%$ \\
\hline $4 \& 5 \& 6$ & $62.71 \%$ & $62.71 \%$ & $62.71 \%$ \\
\hline 18283 & $15.76 \%$ & $15.76 \%$ & $15.76 \%$ \\
\hline $788 \& 9$ & $21.52 \%$ & $21.52 \%$ & $21.52 \%$ \\
\hline
\end{tabular}

This table shows the percentage of responses across our full sample that correspond to a given cell (see $3 \times 3$ matrix in Section 1). Cells are also grouped together: 1\&9 correspond to temporary mis-valuation, $4 \& 6$ correspond to the market becoming misvalued, $3 \& 7$ correspond to a bubble or reverse bubble, and $2 \& 8$ correspond to steady misvaluation. Cell 5 represents efficiency. Cells $4 \& 5 \& 6$ correspond to a fair valuation response, cells $1 \& 2 \& 3$ correspond to an overvaluation response, and cells $7 \& 8 \& 9$ correspond to an undervaluation response. The percentages are computed based on an interval of $0.75,0.5$, or 0.25 standard deviations above and below trend.

Beginning with $4 \& 5 \& 6$, which is invariant to assumptions about what constitutes "equal to trend," $62.7 \%$ of the time respondents believed that the market was currently correctly valued. While this is a solid majority of instances, the corollary is that well over a third of the time there was the view that the market was not currently correctly valued. Therefore, while a belief in current efficiency is modal, thinking that "the market has it wrong" is quite common.

Second, what form does a view that the market is inefficient assume? As stated above, most of the time people thought the market was correctly valued, but when they did not take this view, a belief in undervaluation was a little more common than overvaluation $(21.5 \%$ vs. 15.8\%). A belief in both current and future correct valuation resides in cell \#5 alone, whose size is dependent on how wide our "equal to trend" interval is. Between $33.4 \%$ and $57.1 \%$ (depending on the width of the interval) of the time people believed that markets were then and would remain efficient. While the upper bound is a high percentage of responses, the fact is that it is a far from universal view. As for specific variants of inefficiency, and from this 
point on using a 0.5 SD interval, the only cells with very sparse responses are \#3 and \#7, implying that few saw either bubbles or reverse bubbles in the market. Some saw the market as correctly valued but moving away from correct valuation (11.7\%), while a roughly equal number (11.6\%) saw the market as temporarily misvalued but moving in the right direction. The largest non-efficient group, at $24.5 \%$, saw the market as misvalued but without any selfcorrection coming in the near future.

Table 2: Percentage of Responses across Institutions and over Time

\begin{tabular}{|c|c|c|c|c|c|c|c|c|c|c|c|}
\hline & $100 \%$ & $\begin{array}{c}100 \%- \\
90 \%\end{array}$ & $\begin{array}{c}90 \%- \\
80 \%\end{array}$ & $\begin{array}{c}80 \%- \\
70 \%\end{array}$ & $\begin{array}{c}70 \%- \\
60 \%\end{array}$ & $\begin{array}{c}60 \%- \\
50 \%\end{array}$ & $\begin{array}{c}50 \%- \\
40 \%\end{array}$ & $\begin{array}{c}40 \%- \\
30 \%\end{array}$ & $\begin{array}{c}30 \%- \\
20 \%\end{array}$ & $\begin{array}{c}20 \%- \\
10 \%\end{array}$ & $\begin{array}{c}10 \%- \\
0 \%\end{array}$ \\
\hline 189 & $0.00 \%$ & $0.00 \%$ & $0.00 \%$ & $1.73 \%$ & $1.73 \%$ & $0.43 \%$ & $2.60 \%$ & $3.90 \%$ & $7.36 \%$ & $21.65 \%$ & $60.61 \%$ \\
\hline 486 & $0.00 \%$ & $0.00 \%$ & $0.43 \%$ & $0.00 \%$ & $0.87 \%$ & $0.43 \%$ & $1.73 \%$ & $2.60 \%$ & $8.66 \%$ & $24.68 \%$ & $60.61 \%$ \\
\hline $3 \& 7$ & $0.00 \%$ & $0.00 \%$ & $0.00 \%$ & $0.00 \%$ & $0.00 \%$ & $0.00 \%$ & $0.00 \%$ & $0.00 \%$ & $0.43 \%$ & $2.16 \%$ & $97.40 \%$ \\
\hline 288 & $0.43 \%$ & $0.87 \%$ & $0.87 \%$ & $1.73 \%$ & $2.60 \%$ & $5.19 \%$ & $10.82 \%$ & $10.82 \%$ & $19.05 \%$ & $29.00 \%$ & $19.05 \%$ \\
\hline 5 & $0.87 \%$ & $1.30 \%$ & $6.49 \%$ & $12.55 \%$ & $16.88 \%$ & $17.32 \%$ & $16.02 \%$ & $6.06 \%$ & $9.96 \%$ & $6.49 \%$ & $6.93 \%$ \\
\hline
\end{tabular}

This table shows the percentage of respondents (based on their institution) that are in a given cell (or pair of cells), shown in each row, a given percentage of the time across our full sample, shown in each column. The percentages are computed based on an interval of 0.5 standard deviations above and below trend. Institutions are dropped if the total number of survey responses in the sample is less than five.

Third, considering variation in efficiency beliefs across responding institutions as well as over time and referring to Table 2, it is evident that very few institutions maintain a view that markets remain efficient over different market environments: indeed, less than $1 \%$ of institutions always locate themselves in cell \#5, a far from overwhelming endorsement of efficiency. ${ }^{5}$ Further, less than $10 \%(0.87+1.30+6.49)$ of forecasters believed that the market was efficient $80 \%$ of the time or more. Respondents frequently moved from cell to cell: only about $4 \% / 2 \% / 12 \%$ of answers are located in $1 \& 9,4 \& 6$, or $2 \& 8$, respectively, with $50 \%$ frequency or better. There is also time-variation. For example, Figure 1 shows substantial volatility in the percentage of institutions falling in cell \#5 at each point in time. As few as $10 \%$ of respondents were in cell \#5 in the fall of 2011, and as many as $70 \%$ were in cell \#5 both in 2016 and 2017 . Times when many institutions drop from cell \#5 often occur when there are substantial changes in the stock market, such as a market decline or an increase in volatility. For example, in the fall of 2011 , the DAX dropped substantially. These results are consistent with the adaptive market hypothesis, in that forecaster views on efficiency are time-varying.

This leads to our fourth question: what factors were associated with a belief in efficiency or inefficiency? Some exploratory monthly regressions, shown in Table 3, are suggestive. Here, we aggregate into monthly data and examine the percentage of respondents, by month, that fall within each cell. The explanatory variables are the previous month's 6-month return, the same variable squared (representing volatility), and the percentage of respondents within the same cell/cell group in the previous month (representing persistence). If one believed in efficiency (or rather, a particular form of inefficiency) in the previous month, is there is a higher likelihood of maintaining this view going forward? The answer is yes, since for all cases the lagged own cell/cell group is positive and highly statistically significant. As for past returns, if one witnesses a high [low] past return there will be an increased tendency to see the market as overvalued [undervalued], leading to an expectation of future below-trend [above-trend]

5 The results in Exhibits 2-4 use 0.5 standard deviations to establish the trend. The results for 0.25 and 0.75 standard deviations are qualitatively similar. These results are unreported but available upon request from the authors. 
returns. In the case of the first regression, high returns are consistent with a continued belief in efficiency. In the same regression, past volatility of returns was negatively associated with a continued belief in efficiency: the higher the square of six-month returns, the less likely it is that forecasters believed in efficiency. This is consistent with a view that high volatility is often excessive volatility, and inconsistent with market efficiency (Shiller, 1981). Consistent with this same view, the four non-efficiency cell-groups in Table 3 show positive (two of which are statistically significant at $5 \%$ or better) volatility coefficients, which can be interpreted as high volatility reinforcing one's belief in (a certain type of) inefficiency.

Figure 1: Percentage of Institutions in Cell 5 (Efficiency) across Time

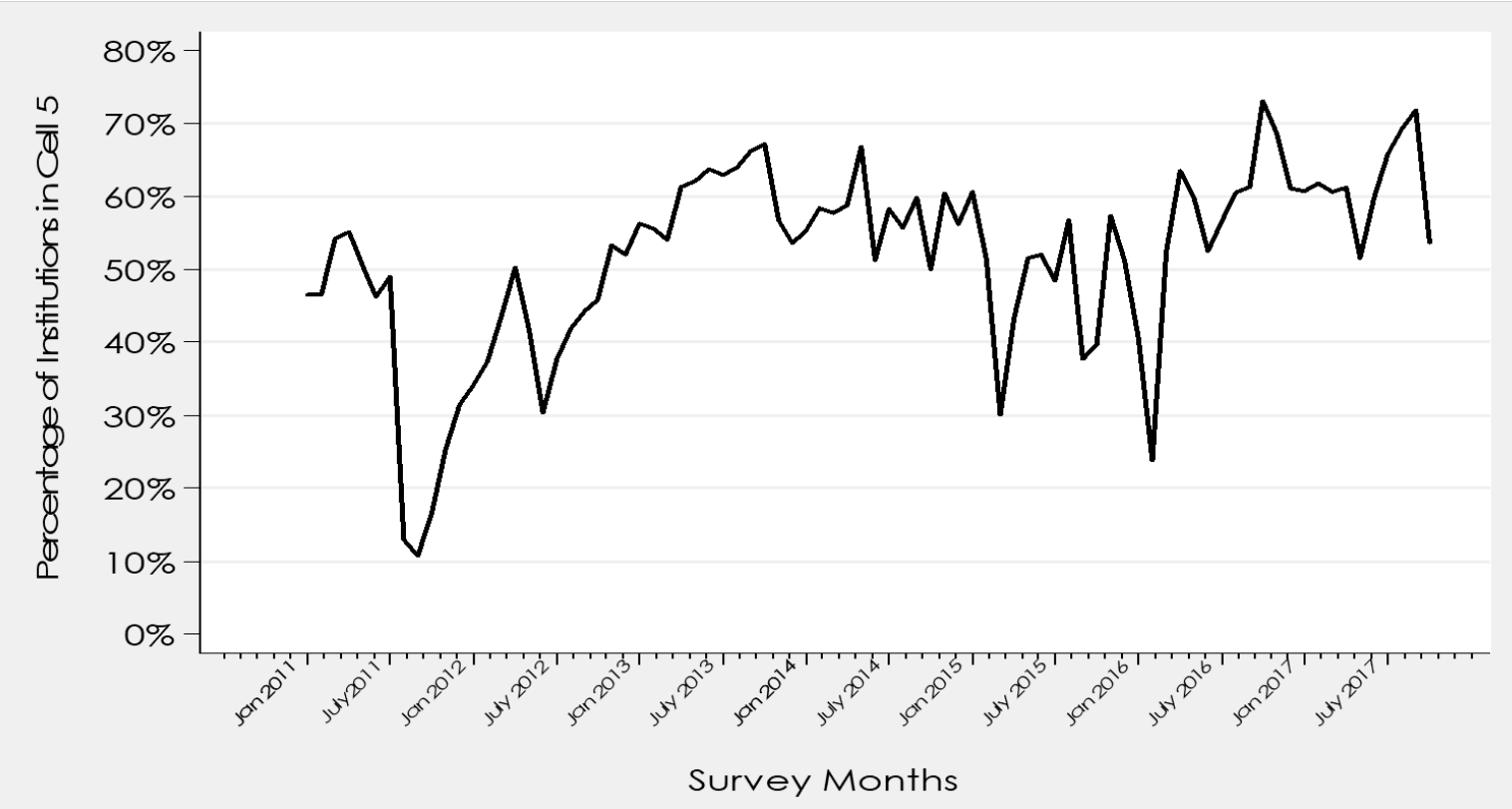

This figure shows the percentage of respondents (by institution) that are in Cell 5 (efficiency) across the sample, based on an interval of 0.5 standard deviations above and below trend. The vertical axis is the percentage of institutions that are in Cell 5, and the horizontal axis lists the years and months.

Table 3: Factors that Influence the Belief in Efficiency

\begin{tabular}{lccccc}
\hline & \% Cell $\mathbf{5}$ & \% Overvalued & \% Undervalued & \% Below Trend & \% Above Trend \\
\hline \multirow{2}{*}{ Constant } & $27.268^{* * *}$ & $2.268^{* *}$ & $5.037^{* * *}$ & $7.960^{* * *}$ & $6.512^{* * *}$ \\
& $(4.65)$ & $(1.99)$ & $(3.57)$ & $(4.94)$ & $(5.28)$ \\
$\mathbf{R}(\mathbf{t}-6: \mathbf{t}-1)$ & $0.423^{* * *}$ & $0.144^{* * *}$ & $-0.444^{* * *}$ & $0.109^{* *}$ & $-0.584^{* * *}$ \\
& $(4.56)$ & $(3.00)$ & $(-4.18)$ & $(2.11)$ & $(-4.61)$ \\
$\mathbf{R}(\mathbf{t}-6: \mathbf{t}-1)^{2}$ & $-0.030^{* * *}$ & 0.004 & $0.017^{* *}$ & 0.005 & $0.019^{* * *}$ \\
& $(-3.64)$ & $(0.79)$ & $(2.55)$ & $(1.39)$ & $(3.10)$ \\
Lag(y) & $0.518^{* * *}$ & $0.785^{* * *}$ & $0.727^{* * *}$ & $0.423^{* * *}$ & $0.253^{* *}$ \\
Adj. $\mathbf{R}^{2}$ & $(5.49)$ & $(12.25)$ & $(9.48)$ & $(4.01)$ & $(2.52)$ \\
\hline
\end{tabular}

This table shows the results of monthly regressions (based on the historical DAX trend that uses $+/-0.5$ standard deviations from the mean), where the dependent variable is listed in the column heading. Newey-West standard errors are used with a lag=6. The first regression uses the percentage of respondents that are within cell 5 (efficiency) as the dependent variable, the next two columns use the percentage of respondents that answer that the DAX is currently over-/under-valued as the dependent variable, and the final two columns use the percentage of respondents that give a forecast below/above the historical trend of the DAX six-month returns. $R(t-6: t-1)$ is the lagged six-month $D A X$ return, $R(t-6: t-1)^{2}$ is the square of this return (to proxy for volatility), and Lag(y) is the previous month's value of that regression's dependent variable. The adjusted $R$-squared value is also reported.

*** indicates significance at a $1 \%$ level, ** at a $5 \%$ level, * at a $10 \%$ level. 


\section{Conclusion}

In this exploratory study, we attempt to infer the market efficiency beliefs of economic forecasters. We do so by examining forecasters' survey responses to both a question on valuation of the German DAX and a six-month forecast of the DAX index. This allows us to examine if the forecasters believe the market is currently correctly valued, and if it will remain so. Our results show that, while typically about half of all forecasters believe that the market is efficient at a given point in time, less than $10 \%$ of forecasters in the sample maintain this view as often as $80 \%$ of the time.

We also show that both past DAX returns and volatility influence forecasters' inferred beliefs. For example, high past returns tend to strengthen the view that the market is and will remain efficient. Additionally, high volatility is associated with a reduced [increased] likelihood of believing markets are efficient [inefficient].

To our knowledge, this is the first attempt to categorize the market efficiency views of forecasters in this fashion. While the cells that each survey response fits into are impacted by our choice of historical trend, these explanatory results appear to be robust. It is clear that the ZEW forecasters view both the current valuation of the stock market and the future outlook for the market differently as market conditions change. Thus, our survey respondents do not view the stock market as always efficient. Rather, it is apparent that they view the market as mostly efficient or efficient most of the time. Our findings also line up with the time-varying efficiency proposed by the adaptive market hypothesis.

Future work could examine if individual characteristics of the respondents or their institution impact their views. For example, are males or females more likely to believe in efficiency? Do more experienced economists/forecasters tend to believe in efficiency more often than inexperienced ones? It is also possible that other economic or market variables, in addition to the ones we examine, matter. Finally, the implications of results such as these could be further explored. Do institutional investors modify their trading strategies in a manner consistent with these findings? Overall, do traders change their behavior when they are more likely to view the market as efficient? The hope is that this exploratory study inspires investigation of these and other questions.

\section{References}

Ackert, L., \& Deaves, R. (2009). Behavioral finance: Psychology, decision-making, and markets. Cengage Learning.

Bartram, S. M., \& Grinblatt, M. (2018). Agnostic fundamental analysis works. Journal of Financial Economics, 128(1), 125-147.

Campbell, J. Y., \& Thompson, S. B. (2008). Predicting excess stock returns out of sample: Can anything beat the historical average? The Review of Financial Studies, 21 (4), 15091531 .

Chen, Y., Kelly, B., \& Wu, W. (2020). Sophisticated investors and market efficiency: Evidence from a natural experiment. Journal of Financial Economics, 138(2), 316-341.

Deaves, R., Lüders, E., \& Schröder, M. (2010). The dynamics of overconfidence: Evidence from stock market forecasters. Journal of Economic Behavior \& Organization, 75(3), $402-$ 412. 
Fama, E. F. (1998). Market efficiency, long-term returns and behavioral finance. Journal of Financial Economics, 49: 283-306.

Fang, J., Kempf, A., \& Trapp M. (2014). Fund Manager Allocation. Journal of Financial Economics, $111(3): 661-674$.

Grossman, S. J., \& Stiglitz, J. E. (1980). On the impossibility of informationally efficient markets. The American economic review, 70(3), 393-408.

Jensen, M. C. (1978). Some anomalous evidence regarding market efficiency. Journal of financial economics, 6(2/3), 95-101.

Kelly, B., \& Pruitt, S. (2013). Market expectations in the cross-section of present values. The Journal of Finance, 68(5), 1721-1756.

Kim, J. H., Shamsuddin, A., \& Lim, K. P. (2011). Stock return predictability and the adaptive markets hypothesis: Evidence from century-long US data. Journal of Empirical Finance, 18(5), 868-879.

Lim, K. P., \& Brooks, R. (2011). The evolution of stock market efficiency over time: A survey of the empirical literature. Journal of Economic Surveys, 25(1), 69-108.

Lo, A. W. (2019). Adaptive markets: Financial evolution at the speed of thought. Princeton University Press.

Manconi, A., Peyer, U., Vermaelen, T. (2019). Are Buybacks Good for Long-Term Shareholder Value? Evidence from Buybacks around the World. Journal of Financial and Quantitative Analysis, 54(5), 1899-1935.

McLean, R. D., \& Pontiff, J. (2016). Does academic research destroy stock return predictability? The Journal of Finance, 71 (1), 5-32.

Purnanandam, A., \& Seyhun, H. N. (2018). Do short sellers trade on private information or false information?. Journal of Financial \& Quantitative Analysis, 53(3).

Shah, S. Z. A., Ahmad, M., \& Mahmood, F. (2018). Heuristic biases in investment decisionmaking and perceived market efficiency. Qualitative Research in Financial Markets.

Shiller, R. J. (1981). The Use of Volatility Measures in Assessing Market Efficiency. Journal of Finance, 36(2), 291-304.

Shleifer, A. (2000). Inefficient markets: An introduction to behavioural finance. OUP Oxford.

Urquhart, A., \& McGroarty, F. (2016). Are stock markets really efficient? Evidence of the adaptive market hypothesis. International Review of Financial Analysis, 47, 39-49.

Welch, I., \& Goyal, A. (2008). A comprehensive look at the empirical performance of equity premium prediction. The Review of Financial Studies, 21 (4), 1455-1508.

Williams, L. V., \& Paton, D. (1997). Does information efficiency require a perception of information inefficiency? Applied Economics Letters, 4(10), 615-617. 